\title{
A Survey of Critical Success Factors of Private Banks in Electronic Banking Services
}

\author{
Nour Mohammad Yaghoubi ${ }^{1}$, Reza Siavashi ${ }^{2} \&$ Roohollah Bahmaei ${ }^{3}$ \\ ${ }^{1}$ University of Sistan and Baluchestan, Zahedan, Iran \\ ${ }^{2}$ Faculty member of Persian Gulf University, Iran \\ ${ }^{3}$ University of Sistan and Baluchestan, Zahedan, Iran \\ Correspondence: Nour Mohammad Yaghoubi, University of Sistan and Baluchestan, Zahedan, Iran. E-mail: \\ yaghoobi@hamoon.usb.ac.ir
}

Received: January 20, 2016

Accepted: March 10, 2016

Online Published: May 9, 2016

doi:10.5539/mas.v10n7p115

URL: http://dx.doi.org/10.5539/mas.v10n7p115

\begin{abstract}
One of the key problems in development of electronic banking services, is the lack of a comprehensive framework to recognize and evaluate the crucial factors of banking success in offering electronic services, which in this study it has been addressed directly. By exploratory factor analysis, the main variables of model are determined and a comprehensive model to identify the key elements of private banks successes in offering electronic services, have been discovered and delineated. This comprehensive model, falls the key elements in six main groups of technical- structural factors, financial factors, cultural- cognitive factors, managerial factors (macro and micro), legal - lawful Factors and qualitative - Security Factors of the System. On the other hand, in each group, the most important items in terms of correlation with the success of electronic banking services are determined. And at last, a comprehensive framework and constructive suggestions in order to solve the issue in electronic banking industry is presented. The model can be an appropriate and valid basis for conducting future researches in the mentioned field.
\end{abstract}

Keywords: key success factors, services, e-banking, exploratory factor analysis

\section{Introduction}

In today's world, with daily growth of technological information; internet-based electronic systems and their connection to the main body of banking business is more evident than ever before, and nowadays e-banking and its unique services are non-removable in society. Concerning the importance of the last line and growing trend of new services in e-banking, the role of scientific and practical researches within this field are more essential than ever, because e-banking is considered as one of the key instruments in implementation, development and facilitating electronic business in all of the countries. So far in this field, authoritative studies have been conducted, such as research by Nikghadam (2013), Basias and Themistocleous, (2013), Sohrabi et al. (2013) and Cabanillas et al. (2013) which represents the growing importance of resolving the obstacles in electronic banking. The main question of this study is to identify and survey the key elements of Iranian private banking successes in offering e-banking services which in this study with an exploratory factor approach to this question, are truly identified and valued which results in a comprehensive outlook to key elements of the banks successes within this field. The main purposes of this study are to recognize and survey the key factors of the banks successes in the country within offering e-banking services and to estimate each effect of these factors on private banks of the country and also to evaluate integration and significant relation among these known factors. Electronic banking can be classified as a subcategory of e-commerce. Previous studies by Donohoe \& Needham (2008), Riasi and Amiri Aghdaie (2013), Gurau, (2008), Riasi and Pourmiri (2015), Lai and Shafer (2005) revealed that implementing e-commerce strategies leads to improved business performance in banks and other firms. The use of electronic banking and providing diversity in the services provided to the customers enables the banks to generate more profit and to become more competitive in the business environment by improving their demand conditions (Amiri Aghdaie et al., 2013; Riasi, 2015). 


\section{Method}

\subsection{Theoretical Literature and Research Background}

\subsubsection{The History of Electronic Banking}

Inconceivable development of information and communication and its propagation to world's monetary and banking market, not only has facilitated affairs for customers of the banks, but also it has transformed the usual banking methods. Attached technology of banks and their exchanges with customers, has been transformed with the advance of information and communication technology (ICT). Amadeh and Jafarpour according to the Ministry of Commerce (2005) divided these developments into four periods. In every period, new technology and electronic banking provides the possibility of increasing speed, quality, accuracy, cost, and the diversity of services.

Table 1. Periods of Development and Evolution of Electronic Banking

\begin{tabular}{|c|c|c|}
\hline Period & $\begin{array}{l}\text { Periods of development and } \\
\text { evolution of } \\
\text { banking }\end{array}$ & Period characteristics \\
\hline First & Front counter automation & $\begin{array}{l}\text { Prevalent in the } 1960 \mathrm{~s} \text {, removing the card from the branch offices, } \\
\text { sending daily circulation of accounts at the end of each day to central } \\
\text { computer, the starting point for computer applications in banking, } \\
\text { Usage: recording documents and converting paper documents into } \\
\text { computer files. }\end{array}$ \\
\hline Second & $\begin{array}{l}\text { Automation of front the } \\
\text { counter }\end{array}$ & $\begin{array}{l}\text { Starting in the } 1970 \mathrm{~s} \text {, branch employees access to current accounts, } \\
\text { continuous information transferring through the use of } \\
\text { telecommunication lines and mainframe computers, Banks' usage of } \\
\text { telecommunication networks in the public company's existing. }\end{array}$ \\
\hline Third & $\begin{array}{l}\text { Customers connecting to the } \\
\text { Accounts }\end{array}$ & $\begin{array}{l}\text { Starting in the middle of } 1980 \mathrm{~s} \text {, customer access to personal } \\
\text { accounts, by phone, (ATM), a smart card or personal computer, } \\
\text { electronic funds transfers, development of customer communication } \\
\text { system with their accounts }\end{array}$ \\
\hline Fourth & $\begin{array}{l}\text { System integration and linking } \\
\text { customers to all banking } \\
\text { operations }\end{array}$ & $\begin{array}{l}\text { Real savings in manpower, creating a fully electronic and intangible } \\
\text { money, all banking services are with electronic }\end{array}$ \\
\hline
\end{tabular}

(Source: Amadeh and Jafarpour, 2009)

We continue by referring to some conducted researches within e-banking:

Table 2. Some Recent Studies about the Electronic Banking

\begin{tabular}{|c|c|c|}
\hline Row & Field of study & Reference \\
\hline 1 & E-banking culture & Fonseca (2014) \\
\hline 2 & E-banking acceptance & Santouridis and kyritsi (2014) \\
\hline 3 & $\begin{array}{l}\text { E-banking acceptance: a unified theory of acceptance and use of technology and perceived } \\
\text { risk application }\end{array}$ & Martins et al. (2014) \\
\hline 4 & A systematic review of internet banking adoption & Hanafizadeh et al. (2014) \\
\hline 5 & Online banking and customer service delivery in Malaysia & Abubakar et al. (2014) \\
\hline 6 & $\begin{array}{l}\text { The impacts of service quality and customer satisfaction on customer loyalty in internet } \\
\text { banking }\end{array}$ & Ariff et al. (2013) \\
\hline 7 & $\begin{array}{l}\text { Development of a quantitative model of the impact of customers' personality and perceptions } \\
\text { on internet banking use }\end{array}$ & Shik yoon et al. (2013) \\
\hline 8 & $\begin{array}{l}\text { Personalized security approaches in e-banking employing flask architecture over cloud } \\
\text { environment }\end{array}$ & Hamidi et al. (2013) \\
\hline 9 & The investigating of barriers of development of e-banking in Iran & $\begin{array}{l}\text { Alinezhad sarokolaei, m., and et al. } \\
\text { (2012) }\end{array}$ \\
\hline 12 & Adoption and utilization of electronic banking & Hoehle et al. (2012) \\
\hline 14 & The impact of 3d e-readiness on e-banking development in Iran & Haghighi et al. (2010) \\
\hline
\end{tabular}




\subsection{Identify the Key Success Factors in Electronic Banking Services}

In order to determine the key success factors of banks in the provision of electronic services to society, all available studies and related research were gathered and reviewed and re-evaluated, and with identifying multiple factors from previous studies, exploratory variables related to the objective research are extracted and presented in Table 3.

Table 3. Effective Variables on Success and Development of Electronic Banking

\begin{tabular}{|c|c|c|}
\hline Row & $\begin{array}{l}\text { Effective variables on the success and development of } \\
\text { electronic banking }\end{array}$ & References \\
\hline 1 & $\begin{array}{l}\text { Quality and attractiveness of the system and designed } \\
\text { website }\end{array}$ & $\begin{array}{l}\text { Kaboutari(2012), Nikghadam(2013), Mentzas et al.(2012), Barne } \\
\text { and Vidgen(2002), Zeng and Yang(2009), Ding et al.(2011) }\end{array}$ \\
\hline 2 & Development and diversification of banking services & $\begin{array}{l}\text { Karjaluoto(2002), Kaboutari(2012), } \\
\text { Mentzas et al.(2012), Kim et al.(2006), Zeng }\end{array}$ \\
\hline 3 & $\begin{array}{l}\text { Ease of use of the designed service system (user-friendly } \\
\text { system) }\end{array}$ & $\begin{array}{l}\text { Basias and Themistocleous(2013), Kaboutari(2012), } \\
\text { Nikghadam(2013), Mentzas et al(.2012), Ding et al.(2011) }\end{array}$ \\
\hline 4 & Quality, correctness and accuracy of information & $\begin{array}{l}\text { (Karjaluoto(2002), Kaboutari(2012), Nikghadam(2013), Mentzas } \\
\text { et al.(2012), Markos et al.(2009), Barne and Vidgen(2002) }\end{array}$ \\
\hline 5 & Support and responsibility systems & $\begin{array}{l}\text { Karjaluoto (2002), Kaboutari (2012), Nikghadam(2013), } \\
\text { Mentzas et al.(2012), Barne and Vidgen(2002), Ding et al.(2011) }\end{array}$ \\
\hline 6 & Quality and attractiveness of existing equipment & $\begin{array}{l}\text { Markos et al.(2009), Kaboutari(2012), Mentzas et al.(2012), } \\
\text { Barne and Vidgen(2002), Zeng and Yang(2009), Ding et } \\
\text { al.(2011) }\end{array}$ \\
\hline 7 & Procedural stability in providing services & Markos et al.(2009), Ding et al.(2011), Hadwich et al.(2010) \\
\hline 8 & Transparency and unequivocally of service & Zeng and Yang(2009), Ding et al.(2011), Hadwich et al.(2010) \\
\hline 9 & Pleasant behavior of bank's personnel with stakeholders & $\begin{array}{l}\text { Markos et al.(2009), Kaboutari(2012), Mentzas et al.(2012), } \\
\text { Barne and Vidgen(2002), Ding et al.(2011), Hadwich et } \\
\text { al.(2010), Basias and Themistocleous(2013) }\end{array}$ \\
\hline 10 & $\begin{array}{l}\text { Strengthening the reliability and stand-by systems in } \\
\text { electronic banking services }\end{array}$ & $\begin{array}{l}\text { Hadwich et al.(2010), Kaboutari(2012), Nikghadam.(2013), } \\
\text { Mentzas et al.(2012),Basias and Themistocleous(2013), Zeng } \\
\text { and Yang(2009), Ding et al.(2011), Markos et al.(2009) }\end{array}$ \\
\hline 11 & $\begin{array}{l}\text { Responsibility and empathy of staffs in provision of } \\
\text { the electronic services }\end{array}$ & Kaboutari(2012), Karjaluoto(2002), Mentzas et al.(2012) \\
\hline 12 & $\begin{array}{l}\text { The existence of appropriate, adequate, transparent and } \\
\text { specialized rules in electronic banking and its crime and } \\
\text { correction }\end{array}$ & Karjaluoto(2002),Nikghadam(2013) \\
\hline 13 & $\begin{array}{l}\text { The existence of supervisory centers and adequate } \\
\text { supervision by the relevant agencies }\end{array}$ & Nikghadam(2013), Karjaluoto(2002) \\
\hline 14 & Security in system and electronic receive services & Markos et al.(2009), Karjaluoto(2002), Mentzas et al.(2012) \\
\hline 15 & Privacy preservation of natural and legal persons & $\begin{array}{l}\text { Basias and Themistocleous(2013), Kaboutari(2012), } \\
\text { Nikghadam(2013), Mentzas et al.(2012) }\end{array}$ \\
\hline 16 & $\begin{array}{l}\text { The existence of credibility and trust in the system and } \\
\text { its development }\end{array}$ & Karjaluoto(2002), Kaboutari(2012), Mentzas et al.(2012) \\
\hline 17 & $\begin{array}{l}\text { Hardware and software infrastructure, ICT, } \\
\text { telecommunications infrastructure and network and other } \\
\text { electronic banking infrastructure. }\end{array}$ & Nikghadam(2013), Pikkarainen et al.(2004) \\
\hline 18 & Internet and available broadband internet & Nikghadam(2013), Pikkarainen et al.(2004) \\
\hline 19 & Integrated information systems & $\begin{array}{l}\text { Basias and Themistocleous(2013), Nikghadam(2013), H.Shah et } \\
\text { al.(2006) }\end{array}$ \\
\hline 20 & $\begin{array}{l}\text { Development of knowledge and expertise about } \\
\text { electronic banking and increase the number of experts in } \\
\text { this field }\end{array}$ & Nikghadam(2013), Pikkarainen et al.(2004) \\
\hline 21 & $\begin{array}{l}\text { Expansion and strengthening payment systems and } \\
\text { electronics sales in the society }\end{array}$ & Kaboutari(2012), H.Shah et al.(2006) \\
\hline 22 & $\begin{array}{l}\text { Equipment development and banking network in the } \\
\text { country }\end{array}$ & Nikghadam(2013), H.Shah et al.(2006) \\
\hline
\end{tabular}




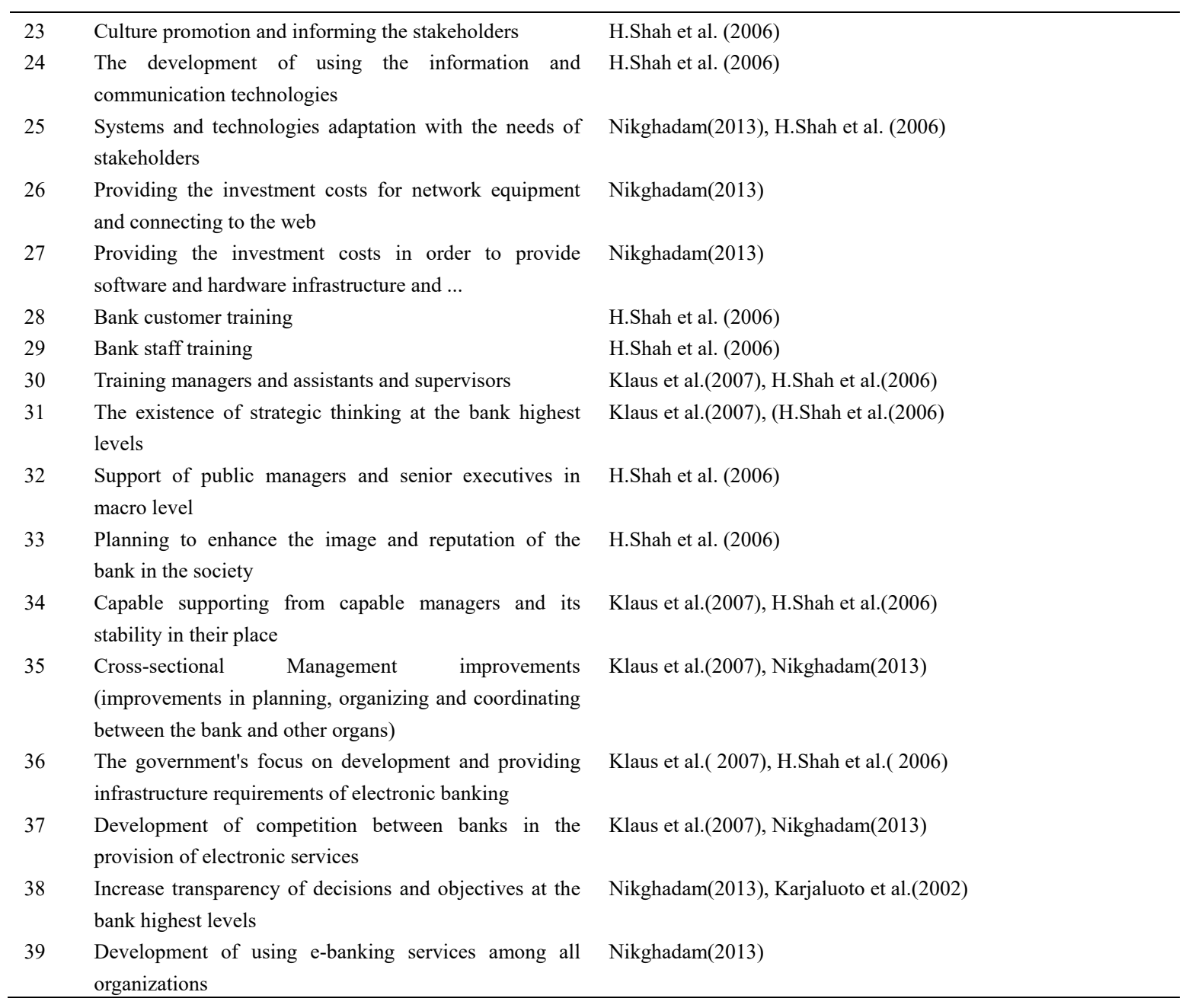

\section{Conceptual Model and Research Methodology}

By using the standpoints of experts related to e-banking and also according to re-studying the research background, six group of the main factors namely as: technical- structural factors, financial factors, culturalcognitive factors, managerial factors (macro and micro), legal - lawful Factors and qualitative - Security Factors of the System, thus a conceptual model took form which is observable in table 2 .

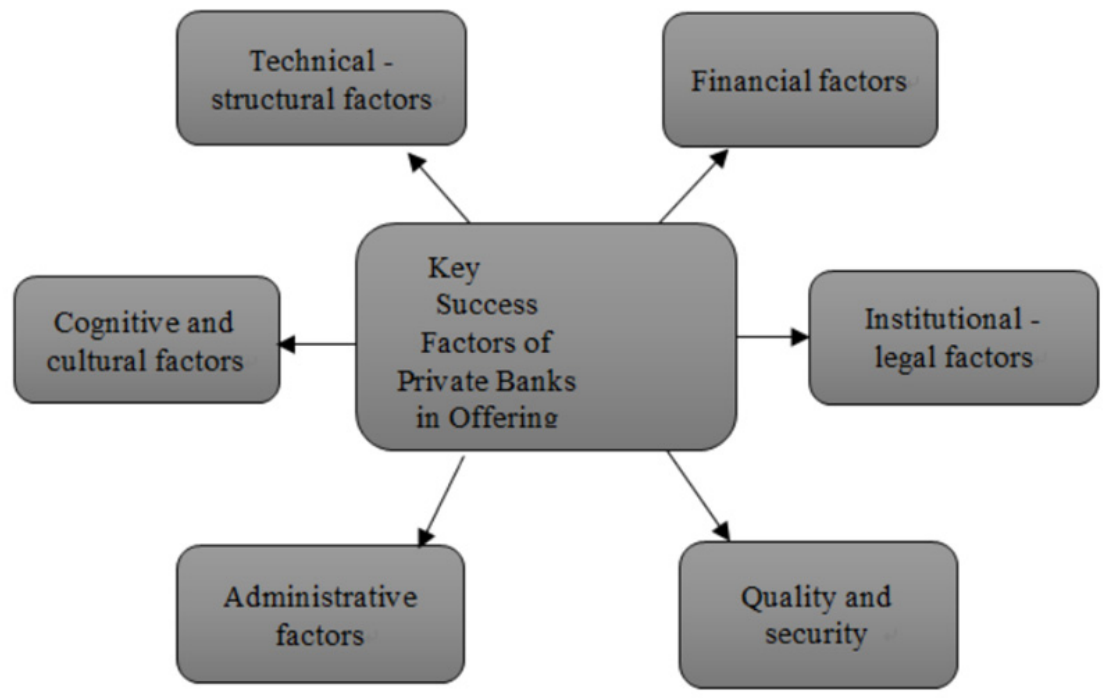

Figure 1. Conceptual model 
This research, in terms of objective applies research and cross-sectional and in terms of performance, its approach is descriptive and exploratory. A questionnaire has been drawn up in the field of the key success factors in provision of electronic services and is designed in Likert 5 point scale survey The reliability of the questionnaire was determined 0.975 by using Cronbach's alpha, which is an appropriate amount and Content validity was also confirmed by supervisor and advisor and some experts in banking field. After collecting the questionnaires, a conceptual model was provided by using the exploratory factor analysis and with considering the research objectives. The current statistic communities are consisted of 150 individuals in whom there are every manager and deputy of Ghavamin bank across the country. In order to measure the sample volume, Morgan table is used which concerning to the number of statistic community members, 108 individuals were selected by employment of "available non-probability sampling" method as sample members.

\section{Research Findings}

Cite the work of those individuals whose ideas, theories, or research have directly influenced your work. They may provide key background information, support or dispute your thesis, or offer critical definitions and data. Citation of an article implies that you have personally read the cited work. In addition to crediting the ideas of others that you used to build your thesis, provide documentation for all facts and figures that are not considered common knowledge.

In this section, all the factors are analyzed by using factor analysis. First, Table adequacy model is given which consists of KMO index, Bartlett index value and the probability value of this index.

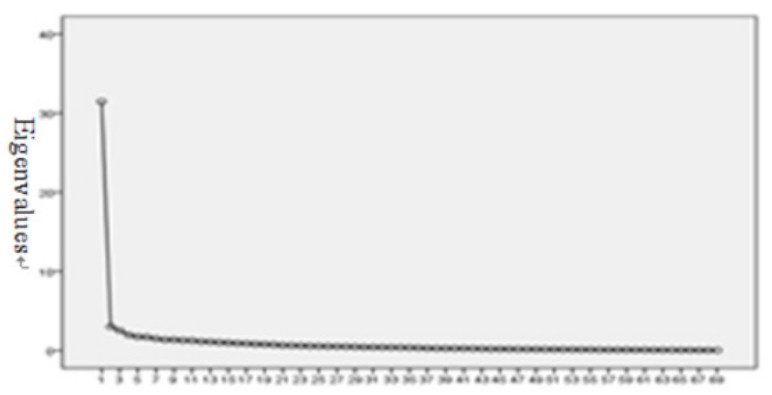

Table 4. KMO and Bartlett test results of the correlation matrix

\begin{tabular}{ll}
\hline Item & Value \\
\hline KMO index & .898 \\
Bartlett's Test & 7049.909 \\
Sig. & .000 \\
\hline
\end{tabular}

Diagram 1. Eigenvalues of critical success factors

Based on the results of KMO test, which is equal to 0.898 , research data are reducible to number of infrastructure factors. Also, result of Bartlett test is equal to 7049.909 which is significant in error which is smaller than 0.01 , it shows that the correlation matrix between the items is not the unit and the identity matrix. This means that, on one hand there is a high correlation between items within each factor and the other hand there is no correlation between the items of one factor and items of other factors. As it can be seen in the graph factor analysis, six factors have eigenvalues greater than one. It means that total of 69 items related to the essential success factors of private banks in provision of electronic services are reducible to six factors. Furthermore, the rotated matrix of factors determines which item is related to the determined factors.

Table 5. Rotated matrix of all the essential success factors of private banks in providing electronic services

\begin{tabular}{l|llllll}
\hline \multirow{2}{*}{ Items } & \multicolumn{5}{l}{ Factors } & \\
\cline { 2 - 6 } & 1 & 2 & 3 & 4 & 5 & 6 \\
\hline Software and hardware facilities at the disposal of the Bank & .682 & .206 & .230 & .170 & .250 & .234 \\
Software and hardware facilities available in the Society & .622 & .080 & .173 & .120 & .174 & -.092 \\
Available Internet bandwidth in the society and available for the & .786 & .273 & .116 & -.009 & .155 & .610 \\
citizens & & & & & & \\
Internet bandwidth and the quality of the bank's existing network & .748 & .229 & .078 & .193 & .122 & .130 \\
IT infrastructure & .725 & .140 & .284 & .322 & .178 & .223 \\
ICT infrastructure & .752 & .171 & .196 & .367 & .032 & .186 \\
Integrated information systems & .571 & .042 & .379 & .195 & .214 & .249 \\
The number of domestic and Organizational Internet service & .451 & .014 & .095 & .430 & .024 & .059 \\
\hline
\end{tabular}




\begin{tabular}{|c|c|c|c|c|c|c|}
\hline \multicolumn{7}{|l|}{ providers } \\
\hline The bank's access to the web & .517 & .164 & .301 & .358 & -.052 & .184 \\
\hline $\begin{array}{l}\text { Expanding range of electronic payment systems (money, } \\
\text { E-cards...) }\end{array}$ & .599 & .271 & .130 & .317 & .144 & .268 \\
\hline $\begin{array}{l}\text { Existence of Modern electronic communication systems with } \\
\text { client }\end{array}$ & .516 & .015 & .091 & .124 & .016 & .123 \\
\hline $\begin{array}{l}\text { Development and diffusion lines and high speed internet in most } \\
\text { areas }\end{array}$ & .413 & .307 & .389 & .409 & .018 & .021 \\
\hline $\begin{array}{l}\text { Development the use of computer hardware and Modern } \\
\text { software in the citizen }\end{array}$ & .370 & .231 & .264 & .356 & .017 & .149 \\
\hline Equipped the banks' 24 -hour virtual branches & .489 & .328 & .322 & .247 & .124 & .223 \\
\hline $\begin{array}{l}\text { Development and integration of the internal banking network in } \\
\text { the country }\end{array}$ & .512 & .281 & .402 & .282 & .076 & .128 \\
\hline market development and strategies of Electronic sales in market & .488 & .243 & .194 & .155 & .338 & .264 \\
\hline $\begin{array}{l}\text { The number of internal experts in the field of IT and electronic } \\
\text { banking }\end{array}$ & .390 & .273 & .302 & .300 & .303 & .062 \\
\hline $\begin{array}{l}\text { Development the Knowledge of local expertise in IT and } \\
\text { Electronic Banking }\end{array}$ & .519 & .150 & .267 & .084 & .317 & -.009 \\
\hline $\begin{array}{l}\text { Developing awareness of Citizens and stakeholders of the } \\
\text { benefits of e-banking }\end{array}$ & .216 & .513 & .505 & .309 & .147 & -.052 \\
\hline $\begin{array}{l}\text { Developing and promoting the culture of use of IT and ICT at } \\
\text { various levels of society. }\end{array}$ & .238 & .516 & .299 & .309 & .147 & .121 \\
\hline $\begin{array}{l}\text { Compatibility between existing technology and customer } \\
\text { requirements }\end{array}$ & .315 & .503 & .420 & .327 & .115 & .091 \\
\hline Culturing and effective informing & .328 & .536 & .317 & .364 & .029 & -.120 \\
\hline
\end{tabular}

\section{Discussions and Conclusions}

This research aims to survey the key success factors of the country's private banks in proving the electronic banking services. It is obvious that degree of importance and effectiveness of efficient factors are different in success of private banks for providing electronic services. So, by using exploratory factor analysis, factor loadings (correlations between items and categories) of all items were also identified. Thus, in this section, the results of research for six factors are separately analyzed. The outcome of importance meter of technical structure factors by exploratory factor analysis suggests that, from standpoint of experts, the current Internet bandwidth factor in citizen's disposal with a factor loading of 0.786 has the maximum factor loading in the entire technical - structure factors, and also, Information and communication technologies infrastructure factor is in second place with a factor loading of 0.752 and the Internet bandwidth and network quality in the bank in third place with a factor loading of 0.748 . The importance meter results of cognitive and cultural factors by exploratory factor analysis suggest that from standpoint of experts, the effective knowledge with a factor loading of 0.786 has the maximum factor loading. After that, developing and promoting the use of IT and ICT at different levels of society (with a factor loading: 0.516), awareness development of citizens and stakeholders on benefits of electronic banking (with a factor loading: 0.513) and adaptation of existing technologies to meet customer needs (with a factor loading: 0.503) are placed in the following ranks. In factor of providing the costs of investment in infrastructure and telecommunications platforms with a factor loading of 0.552 has the maximum factor loading in the eyes of experts, and also desired credit for the costs of connecting to the web with a factor loading of 0.513 , Allocation of costs for upgrading and development of satellite and computer in bank with a factor loading of 0.511 and appropriate and desired cost of provision of electronic banking services to customers with a factor loading of .467 are ranked second, third and fourth. Among financial factors, the factor of controlling the perceived risk in the electronic banking system with a factor loading of 0.747 has the maximum factor loading and then tendency and support of the bank's senior managers to development of e-banking is in the second place with a factor loading of 0.695 and supporting of active organizations in the field of electronic banking services is in the third place with a factor of 0.659 loading. The analysis of juridical-legal elements illustrates that, from the viewpoint of experts, the existence of regulatory organizations with a factor loading of 0.570 has the maximum factor loading which is in the first place, and then, the regulatory reform and development of electronic banking is in the second place with a factor loading of 0.528 and transparency of citizen's rights and consumers is in the third place with a factor loading of 0.487 . The importance meter results 
of administrative factors in both micro and macro, by exploratory factor analysis suggest that, from the viewpoint of experts, the factor of controlling the perceived risk in the electronic banking system with a factor loading of 0.747 has the maximum factor loading and then tendency and support of the bank's senior managers to development of e-banking is in the second place with a factor loading of 0.695 , and supporting of active organizations in the field of electronic banking services is in the third place with a factor of 0.659 loading. . The importance meter results of quality and security of the system factors by exploratory factor analysis suggest that, from the viewpoint of experts, the factor of user-friendly systems and tools to provide electronic services with a factor loading of 0.747 has the maximum factor loading among all quality-security factors, which is in the first place, and then diversity and development range of electronic banking services is in the second place with a factor loading of 0.729 , procedural stability of electronic banking services is in the third place with a factor loading of 0.711 . Given these values are positive, it can be concluded that strengthening of every 6 factor can lead to the success of private banks in the provision of electronic services to customers. In this context and according to the results, evaluation and overall fitting of the proposed model by using structural equation techniques and AMOS software, assessing the current situation of Ghavamin Bank and other private banks with the aid of this model and identifying the present status are among the subjects that would be offered to the future researchers.

\section{References}

Abubakar, A. A. et al. (2014). Online Banking and Customer Service Delivery in Malaysia: Data Screening and Preliminary Findings. Procedia - Social and Behavioral Sciences, 129(15), 562-570.

Alinezhad Sarokolaei, M., \& et al., The Investigating of Barriers of Development of E-banking in Iran. Procedia -Social and Behavioral Sciences, 62(24), 1100-1106. 2012.

Amade, H., \& Jafarpour, M. (2009). Evaluating the Barriers and solutions for e-banking development in the country's private banks. Journal of Management Executive, 9(2), 13-38.

Amiri, A. S. F., Seidi, M., \& Riasi, A. (2012). Identifying the Barriers to Iran's Saffron Export by Using Porter's Diamond Model. International Journal of Marketing Studies, 4(5), 129-138.

Ariff, M., et al. (2013). The Impacts of Service Quality and Customer Satisfaction on Customer Loyalty in Internet Banking. Procedia - Social and Behavioral Sciences, 81(28), 469-473.

Barnes, S. J., \& Vidgen, R. T. (2002). An integrative approach to the assessment of e-commerce quality. Journal of Electronic Commerce Research, 3(3), 114-27.

Basias, N., \& Themistocleous, M. (2013). SOA adoption in E-Banking. Journal of Enterprise Information Management, 26(6), 719-739.

Bauer, K., \& Hein, S. (2006). The effect of heterogeneous risk on the early adoption of Internet banking technologies. Journal of Banking \& Finance, 30(6), 1713-1725.

Cabanillas, F. L. et al. (2013). The determinants of satisfaction with e-banking. Industrial Management \& Data Systems, 113(5), 750-767.

Daniela, R., \& Octavian, D. (2004). The Adoption Electronic Banking Services in Developing Countries. Journal of Electronic Commerce Research, 6, 143-156.

Ding, D. X., Hu, P. J. H., \& Olivia, R. L. (2011). E-SELFQUAL: A scale for measuring online self-service quality. Journal of Business Research, 64, 508-515.2011.

Donohoe, H. M., \& Needham, R. D. (2008). Internet-based ecotourism marketing: Evaluating Canadian sensitivity to ecotourism tenets. Journal of Ecotourism, 7(1), 15-43.

Foley, P., \& Jayawardhena, C. (2000). Changes In The Banking Sector The Case Of Internet Banking in The UK. Internet Research: Electronic Networking Applications and Policy, 10 (1), 19-31.

Fonseca, J., (2014). E-banking culture: A comparison of EU 27 countries and Portuguese case in the EU 27 retail banking context. Journal of Retailing and Consumer Services, 21(5), 708-816.

Gorilas, S., Tambouris, E., \& Boukis, G. (2003). Investigation of Electronic .Government, Archetypon S.A., Athens, Greece, 10-26.

Gurau, C. (2008). Integrated online marketing communication: implementation and management. Journal of Communication Management, 12(2), 169-184.

H.Shah, M., et al. (2006). A Survey of Critical Success Factors in e-Banking. Journal of Electronic Commerce in 
Organizations (JECO), 23, 32-51.

Hadwich, K., Georgi, D., Tuzovic, S., \& Büttner, M. (2010). Perceived quality of e-health services: A conceptual scale development of e-health service quality based on the C-OAR-SE approach. International Journal of Pharmaceutical and Healthcare Marketing, 4(2), 112-136.

Haghighi, M., et al. (2010). The impact of 3D e-readiness on e-banking development in Iran: A fuzzy AHP analysis. Expert Systems with Applications, 37(6), 4084-4093.

Hamidi, N., et al. (2013). Personalized Security Approaches in E-banking Employing Flask Architecture over Cloud Environment. Procedia Computer Science, 21, 18-24.

Hanafizadeh, P., et al. (2014). A systematic review of Internet banking adoption. Telematics and Informatics, 31(3), 492-510.

Harris, L. (2002). The Ethics of eBanking. Journal of Electronic Commerce Reasearch, 3(2), 56-76.

Hoehle, H., et al. (2012). Three decades of research on consumer adoption and utilization of electronic banking channels: A literature analysis. Decision Support Systems, 54(1), 122-132.

Kaboutari, J. (2012). Applying ES-QUAL approach in the evaluation and ranking of effective factors on Service quality of ATMs, case study: Bank of Bushehr exports, Department of Business Administration, University of Persian Gulf.

Karjaluoto, H., Pento, T., \& Mattila, M. (2002). Factors Underlying Attitude Formation Towards Online Banking in Finland. International Journal of Bank Marketing, 26(6), 261-272.

Kim, M., Kim, J. H., \& Lennon, S. J. (2006). Online service attributes available on apparel retail web sites: An e-S-QUAL approach. Managing Service Quality, 16(1), 51-77.

Lai, P. H., \& Shafer, S. (2005). Marketing ecotourism through the Internet: An evaluation of selected eco lodges in Latin America and the Caribbean. Journal of Ecotourism, 4(3), 143-160.

Marianne, A., Kolodinsky, J. M., \& Hogarth, J. M. (2004). The Adoption of Electronic Banking Technologies by US Consumers. International Journal of Bank Marketing, 22(4), 25-238.

Markos, A., Patsioura, F., \& Kitsiou, S, Evaluation of Greek public hospital websites. International conference on E-business - ICE-B, 5, 123-139.

Martins, C., et al. (2014). Understanding the Internet banking adoption: A unified theory of acceptance and use of technology and perceived risk application. International Journal of Information Management, 34(1), $1-13$.

Mentzas, G., \& Papadomichelak, X. (2012). E-GovQual: A multiple-item scale for assessing e-government service quality. Journal of Government Information Quarterly, 29, 98-109.

Nikghadam, S. (2013). Effects of Iranian online behavior on the acceptance of internet banking. Journal of Asia Business Studies, 7(2), 123-139.

Pikkarainen, T. et al. (2004). Consumer acceptance of online banking: anextension of the technology acceptance model. Internet Research, 14(3), 224-235.

Riasi, A. (2015). Competitive Advantages of Shadow Banking Industry: An Analysis Using Porter Diamond Model. Business Management and Strategy, 6(2), 15-27.

Riasi, A., \& Amiri, A. S. F. (2013). Effects of a Hypothetical Iranian Accession to the World Trade Organization on Iran's Flower Industry. Consilience: The Journal of Sustainable Development, 10(1), 99-110.

Riasi, A., \& Pourmiri, S. (2015). Effects of online marketing on Iranian ecotourism industry: Economic, sociological, and cultural aspects. Management Science Letters, 5(10), 915-926.

Santouridis, I., \& Kyritsi, M, Investigating the Determinants of Internet Banking Adoption in Greece. Procedia Economics and Finance, 9, 501-510. 2014.

Shik, Y. H., \& Barker, S. L. (2013). Development of a quantitative model of the impact of customers' personality and perceptions on Internet banking use. Computers in Human Behavior, 3, 1133-1141.

Sohrabi, M. et al. (2013). Critical Success Factors For the Adoption of E-Banking in Malaysia. International Arab Journal of E-Technology, 3(2), 76-82.

Wendy, W., Wan, N., Luk, C. L., Cheris, W., \& Chow, C. (2005). Customers' Adoption of Banking Channels In Hong Kong. Journal of South China University of Technology, 4, 34-61. 
Zeng, Y., \& Yang, L. h. (2009). Multi-Maintenance Management System Based on Prevention Maintenance. Journal of South China University of Technology (Natural Science Edition), 108, 132-167.

\section{Copyrights}

Copyright for this article is retained by the author(s), with first publication rights granted to the journal.

This is an open-access article distributed under the terms and conditions of the Creative Commons Attribution license (http://creativecommons.org/licenses/by/3.0/). 